
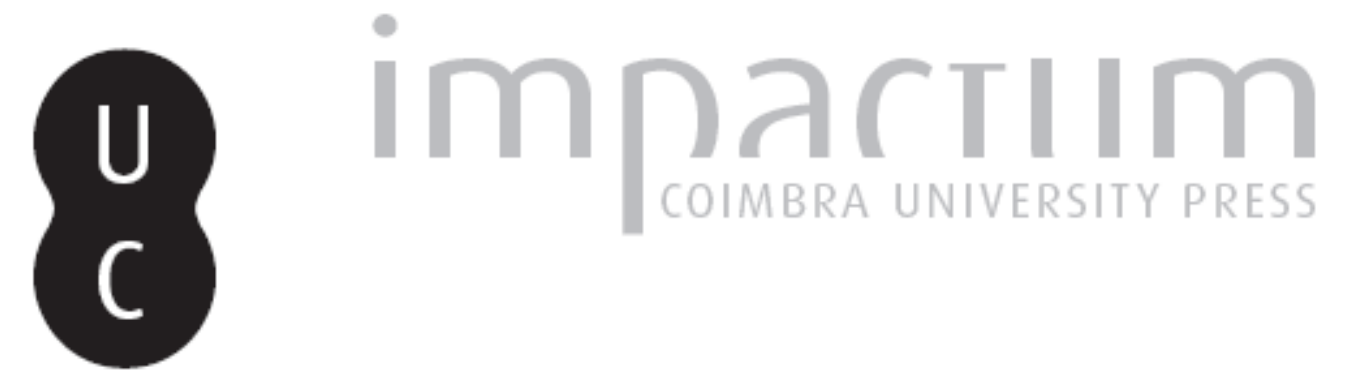

\title{
[Review] TRABATTONI, Franco, Essays on Plato's Epistemology. Ancient and medieval philosophy
}

Autor(es): Zucchetti, Nicholas

Publicado por: Imprensa da Universidade de Coimbra

URL persistente:

URI:http://hdl.handle.net/10316.2/43599

DOI:

DOI:https://doi.org/10.14195/2183-4105_17_7

Accessed : $\quad$ 26-Apr-2023 13:48:35

A navegação consulta e descarregamento dos títulos inseridos nas Bibliotecas Digitais UC Digitalis, UC Pombalina e UC Impactum, pressupõem a aceitação plena e sem reservas dos Termos e Condições de Uso destas Bibliotecas Digitais, disponíveis em https://digitalis.uc.pt/pt-pt/termos.

Conforme exposto nos referidos Termos e Condições de Uso, o descarregamento de títulos de acesso restrito requer uma licença válida de autorização devendo o utilizador aceder ao(s) documento(s) a partir de um endereço de IP da instituição detentora da supramencionada licença.

Ao utilizador é apenas permitido o descarregamento para uso pessoal, pelo que o emprego do(s) título(s) descarregado(s) para outro fim, designadamente comercial, carece de autorização do respetivo autor ou editor da obra.

Na medida em que todas as obras da UC Digitalis se encontram protegidas pelo Código do Direito de Autor e Direitos Conexos e demais legislação aplicável, toda a cópia, parcial ou total, deste documento, nos casos em que é legalmente admitida, deverá conter ou fazer-se acompanhar por este aviso.

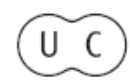


ISSN 2079-7567 eISSN 2183-4105

0

\section{Established 1989}

http://platosociety.org/

\section{Papers}

Cristina lonescu Elenchus, Recollection, and the Method of Hypothesis in the Meno

Lucas Soares

La relectura positiva de la tradición poética griega en el Banquete de Platón

Etienne Helmer Le commerce de la vérité: économie et commerce dans les Lois de Platon

Alan Pichanick

Socratic Silence in the Cleitophon

Thanassis Gkatzaras The Form of the Good in Plato's Timaeus

James M. Ambury Dialectical Epimeleia:

Platonic Care of the Soul and Philosophical Cognition
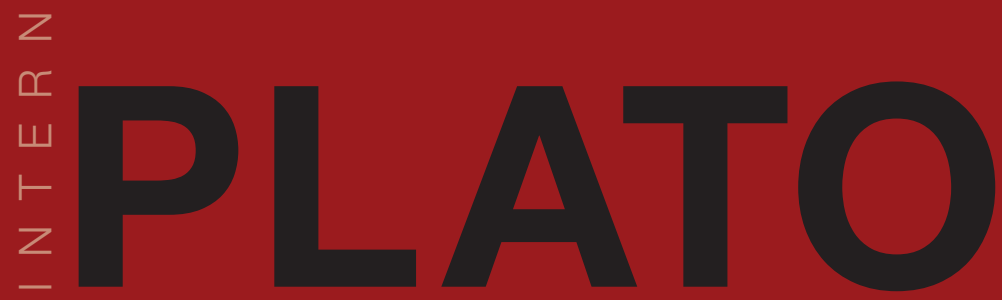

Book Reviews

Nicholas Zucchetti

Essays on Plato's Epistemology by Franco Trabattoni

Alan Pichanick

Socrates and Self-Knowledge by Christopher Moore
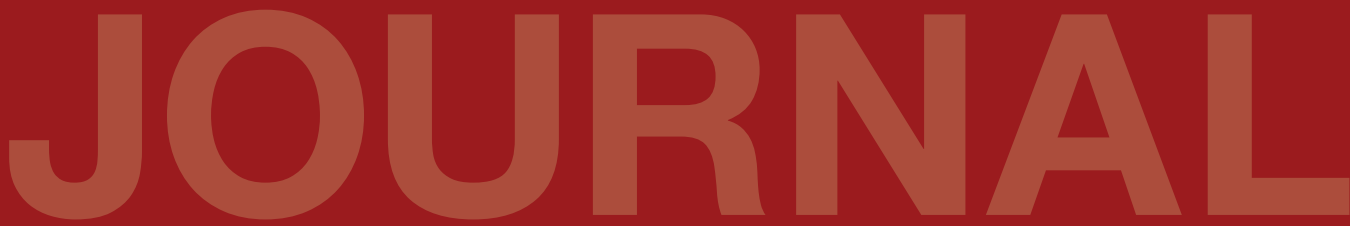

Société Platonicienne Internationale

Associazione Internazionale dei Platonisti

Sociedad Internacional de Platonistas

Internationale

Platon-Gesellschaft

Imprensa da

Universidade

de Coimbra

Coimbra

Universiy

Press 


\section{Franco Trabattoni,} Essays on Plato's

\section{Epistemology. Ancient and medieval philosophy \\ - Series 1, 53.}

Leuven: Leuven University Press, 2016. Pp. 336. ISBN 9789462700598. €80.00.

\section{Nicholas Zucchetti}

KU Leuven

nicholas.zucchetti@kuleuven.be

\section{TRABATTONI'S INTERPRETATION OF PLATO'S EPISTEMOLOGY}

Essays on Plato's Epistemology is the first book-length publication in English on Plato by Franco Trabattoni (henceforth T.); a renowned Italian Plato scholar. The book collects fourteen essays on Plato's epistemology, written between 2002 and 2013. ${ }^{1}$ In the first part of this review I consider the book's arguments, many of which shed new light on some of the most extensively discussed issues in Plato's epistemology, challenging the reader to rethink the assumptions and arguments supporting the traditional interpretations. Then, in the second part, I outline some considerations.

The first significant contribution arises from the way in which $\mathrm{T}$. places his view between two competing interpretations. According to the first group, the unitarians, there is a set of fixed and coherent beliefs that run throughout Plato's dialogues; at the heart of Plato's philosophical project there is a single picture that is explored from different view-points. According to the second group, the developmentalists, Plato's dialogues are filled with twists and turns. Just as it is common to speak of "early" and "late" Heidegger or Wittgenstein, so analogously, these scholars argue, it is natural to speak of different stages in Plato's thought as well: the views expressed in the early dialogues differ from those of the middle dialogues, which in turn differ from those of the late dialogues. One of the most compelling reasons for denying unity in Plato's thought is found in the Theaetetus. Although this dialogue comes after the positive results Plato has achieved in the middle dialogues, it has an aporetic nature. What is more, explicit references to the Forms, which are traditionally taken to be at the core of Plato's thought, are entirely lacking in the Theaetetus. 
In addressing this issue, T. suggests an unorthodox solution. On the one hand, he criticizes Francis Macdonald Cornford (1935) - one of the most influential unitarian scholars - and likeminded scholars who argue that: ${ }^{2}$

(C1). 'No definition of epistêmê may be provided without referring to the Ideas' (p. 65). That is to say, Forms are the only authentic objects of knowledge. Since the Theaetetus seeks to extract knowledge from sensible objects, it is doomed to end in an aporia.

(C2). It is necessary to exorcise the monstrous presence of skepticism from Plato's thought (p. 101). Plato's philosophical thought has a conclusive character; its aim is to fully grasp the Ideas.

T. rejects both claims by arguing that:

(T1). C1 is untenable because while it is true that the first part of the Theaetetus refers to doxa as the knowledge of sensible reality (what T. calls doxa ), it is also true that the second and third parts of the dialogue refer to a different type of knowledge, i.e. intellectual knowledge. This later type of knowledge is not the result of sense-perception but rather of the judgment (what T. calls doxa $a_{\mathrm{i}}$ ) that is inwardly stated by the soul itself when it ends the inquiry (p.19). Since Cornford's analysis addresses only sensible knowledge, his interpretation should be rejected.

(T2). C2 is untenable insofar as it wrongly assumes that Plato's philosophical thought is either dogmatic or sceptical, excluding the possibility of a third alternative. More precisely, on the premises that (C2.1) Plato's philosophical thought is dogmatic, i.e. human knowledge fully grasps Forms, which are the only objects of knowledge, and that (C2.2) the Theaetetus denies the possibility of knowledge as it ends with an aporia, Cornford reaches the conclusion that (C2.3), in the Theaetetus, Plato shows what knowledge is not (pars destruens). Since Plato is not a sceptic, the Theaetetus clarifies that epistêmê is not sensible knowledge but rather knowledge of the Forms.

T. denies Cornford's conclusion (C 2.3) by rejecting (C2.1). He argues that 'Plato believes the achievement of philosophical truth to never be final in character, yet without falling back into skepticism' (p. 159 n. 38). By assuming that knowledge is provisional and that it consists in the intellectual knowledge of the second and third part of the dialogue, T. argues that it is possible to find something that Plato held to be true (pars construens) in the Theaetetus ( $\mathrm{p}$. $26)$. This, according to T., is the precisely the impossibility of reaching infallible knowledge, since human knowledge is always provisional and contaminated with a doxastic element.

T.'s interpretation appeals to two central arguments: (T2.1) knowledge does not consist in sense-perception (pars destruens); (T2.2) intellectual knowledge is not infallible because human thought can never free itself from doxa, and thus from the possibility of error (pars construens). This does not entail, as the author clarifies, that Plato denies 'that men may have access to genuine truth (as opposed to falsehood); what he denies is that men may be certain to have acquired this in an incontrovertible and absolute fashion' (p. 81).

In order to corroborate this thesis, T. turns firstly to the object of the Theaetetus, and argues that the epistêmê under enquiry is conceived as final and infallible knowledge; that type of knowledge that in the Symposium is said to be the privilege of the Gods (pp. 68-70). Secondly, by focusing on the second conception of doxa $\left(\right.$ doxa $\left._{\mathrm{i}}\right)$, he argues that there is a constitutive 
weakness in our human nature that prevents us from reaching the infallible knowledge that is the object of the Theaetetus. The evidence for this second argument comes from the passage on thought as an inner dialogue. T.'s interpretation runs as follows: if thinking (Theait. $189 \mathrm{e}$

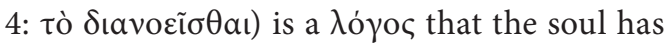

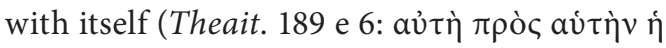
$\psi v \times \grave{\eta}$ ) and if the conclusion that the soul reaches through question and answer is a $\delta$ ó $\xi \alpha$, then it is not possible to disentangle $\lambda$ ó $\gamma \circ$ from $\delta$ ó $\xi \alpha$. $\Lambda$ ó $о \varsigma$ and $\delta$ ó $\xi \alpha$ are intrinsically interwoven with each other and, as a result, a subjective element is introduced into human thought; the

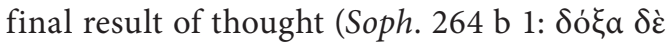

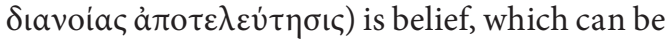
either false or true (Soph. 264 a 8). In principle any judgment could eventually turn out to be false, and thus there could be truth but not certainty. This weakness of the $\lambda$ ópos is what impedes human thought from reaching infallible knowledge.

On the other hand, turning to the second group, i.e. the developmentalists, T. agrees with them in holding that there is a pars construens in the Theaetetus even without mentioning Forms. He nonetheless holds a Unitarian view: the framework of Plato's Theaetetus is a recurrent pattern that occurs throughout Plato's dialogues (p. 92). T. detects striking similarities between the theory of knowledge of the Theaetetus and that of the Phaedo, the Republic, the Symposium, the Cratylus and so forth. The whole book can be conceived as an attempt to show that his interpretation of the Theaetetus is consistent with the framework of the other dialogues. For the present, suffice it to refer to the Phaedo. T. focuses on the second sailing passage (pp. 42-43) where, as is well known, Socrates is looking for the causes of everything, why it comes-to-be, why it passes away, and why it is (Phaid. 96 a 8-10). At first,
Socrates turns to the philosophers of nature but he soon comes to realize that the method they employ is unsatisfactory; it is impossible to attain knowledge of reality through senseperception. As a result of this shortcoming, he introduces the metaphor of the second sailing

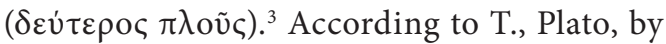
introducing this metaphor, shows that, in line with the epistemology of the Theaetetus, (1) knowledge is not a result of sense-perception and (2) although intelligible knowledge is not worse than sensible knowledge, it is incapable of reaching infallibility (Phaid. 100 a 1-3). Following the metaphor, the point is that we watch an eclipse of the sun only by looking at its reflection; that is to say we can know intelligible reality only indirectly, investigating the

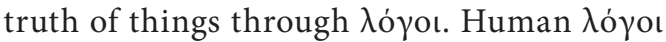
can at most be true but never infallible since this would require the possibility to verify the propositions that describe reality via a direct contact with reality; something that for $\mathrm{T}$. is absolutely out of reach for humans.

The second intriguing idea that runs through this book is T.'s interpretation of the Two Worlds Theory (TW). ${ }^{4}$ Until recent times, it was widely believed that, according to Plato, there is a clear-cut distinction between the sensible world and the intelligible world. The former is the world of opinion: one can have beliefs but not knowledge about sensible objects; i.e. the sensible world is the object of beliefs. The latter is the world of knowledge: one can have knowledge but not beliefs about transcendent Forms; i.e. the intelligible world is the object of knowledge.

Now, this theory has been the object of two contending interpretations. The supporters of the first group - following the most prominent traditions in the 20 th century, i.e. the analytical and the hermeneutic traditions - have freed Plato's philosophical thought from its 
metaphysical import and focused instead on language: human beings are within language and it is only in this sphere that being has a meaning. That is to say, according to these scholars, Plato holds that language cannot be transcended, consequently knowledge has a propositional character (Forms are grasped through propositions). T. partially agrees with this thesis and argues that, for Plato, the highest type of (human) knowledge has a linguistic character. However, he disagrees in that propositional knowledge has an intrinsic weakness which prevents it from becoming infallible. Human thought and language cannot be disentangled from doxa, and thus infallible knowledge is not expressible in language and thought. Logos and eidos intersect one another without being identical. That is to say, there is an ineliminable otherness between the two which cannot be overcome; reality is like a prism that is imperfectly mirrored in thought and language.

The supporters of the second group, on the other hand, claim that knowledge in Plato has an intuitive character, that is to say, Forms are grasped intuitively. Nonetheless they differ on other issues: while some claim that eidos is the object of vision which ultimately coincides with logos, others posit a radical difference between eidos and logos, making thought and language inadequate for knowledge. T. agrees with these scholars in that infallible knowledge is the result of an intuition, not of human thought (pp. 210-212). However, he disagrees with the claim that men possess the capacity to grasp Forms in their earthly life. Since Forms are not immanent in this world but separated, they cannot be the object of a direct vision.

T. seeks to transcend this debate altogether by rejecting the meeting point between the supporters of the two aforementioned lines of interpretations. T. argues that the supporters of both of the two groups assume that 'Plato's TW and the notion of the actual transcendence of the ideas compared to sensible reality are not to be taken seriously' (p. 212) because Plato's two worlds can be reduced to one realm. The underlying assumption is that embodied human souls can attain knowledge of the Forms already in their earthly life, and thus that it is not necessary to postulate a second transcendent world. T., on the contrary, denies this and insists on the importance of Plato's TW and the transcendent realm of Forms: the metaphysical distinction between Forms and sensible objects is ineliminable. The core idea of his thesis is that 1) Forms exist in a transcendent world and that 2) this transcendent world becomes the object of human knowledge only when the soul is detached from the body; 'only in a world of purely immaterial souls and forms, completely different from the one we all live in, may the very high standards required by the Platonic true notion of knowledge be fulfilled' (p. 41). This is the perfect world, which in the Phaedo is said to be grasped by the soul itself by itself when, separated from the body (Phaid. $64 \mathrm{c}$ ) and 'using pure thought alone, tries to track down each reality pure and by itself' (Phaid. 66 a 1-3).

\section{SOME CRITICAL REMARKS ON TRABATTONI'S INTERPRETATION}

In what follows, I will outline some considerations on the two points I have stressed in the previous chapter. Let me start from the second point about Plato's TW. T.'s insistence on the transcendence of the world of Forms seems to be persuasive. ${ }^{5}$ This becomes clear, it may be argued, if we turn to Plato's characterization of the realm of Forms. According to Plato, Forms, unlike sensible objects, are not: 
(1) dependent upon spatial-temporal alterations;

(2) dependent upon the perspectives or circumstances from which they are either perceived or thought. ${ }^{6}$

If Forms are independent from (1) and (2), how do we positively characterize them? One interesting way of looking at them is by focusing on their simplicity. ${ }^{7}$ Forms are absolutely

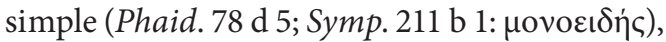
that is to say they only possess the property exhibited by their names. This implies that it is not possible to ascribe to them properties other than their own. The form of beauty or the beautiful itself is just beauty, is uniformly beautiful. Thus, contrary to the beautiful things of the sensible realm, the beautiful itself cannot be 'beautiful in one respect and ugly in another, or beautiful at one time and not at another, or beautiful by one standard and ugly by another, or beautiful in one place and ugly in another because it is beautiful to some people but ugly to others.' ${ }^{8}$ The beautiful itself is just beautiful, period. It is the being that really is, the true being (Phaidr. 247 e 2: ö $v \tau \omega \varsigma$ öv) that is separated from the mode of being of the sensible realm; this latter is nothing but a sensible image (Phaidr. 250 a, Tim. 29 a-b) of the former, it is what we now say that is (Phaedr.

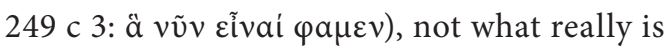

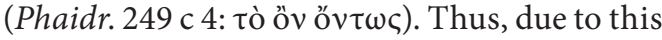
difference, images cannot reach the simplicity and the mode of being of Forms: besides the Fx property of the Form $\mathrm{x}$, they will also exhibit Fn other properties. In the words of the Phaedrus, they will also possess colors and shapes, of which Forms are devoid (Phaidr. 247 c 3-7).

Now, this ontological deficiency, besides applying to sensible images, also applies to spoken images or $\lambda$ ó ot: $^{9}$ as Socrates argues, none of our earthly poets has ever sung or ever will sing the region above the heavens (Phaidr. 247 c 3:

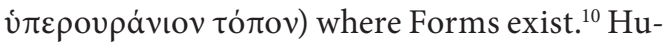
man souls can only feed upon $\delta$ o $\xi \alpha \tau \tilde{n}$ (Phaidr.

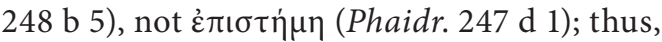
due to this insufficiency, human's $\lambda$ ó $\gamma o$ s will never grasp the true being. Language, just like the sensible realm, is an imitation of true being. At most it resembles the being that really is by saying something true about it, but it will never become identical with it. ${ }^{11}$

Turning to the first point, T.'s analysis focuses, as I have explained above, on the second conception of doxa $\left(\right.$ doxa $\left._{\mathrm{i}}\right)$. This type of doxa occurs in the third attempt to explain false belief in the Theaetetus, i.e. in the other-judging (allodoxia) passage (Theait. 189 b 10-190 e 4); an obscure passage of the text that is a matter of scholarly controversy. Most notably, it is not clear whether the objects of this passage are general concepts - such as "the beautiful is ugly" or "the just is unjust"- or individual objects - such as "Theaetetus is beautiful" or "Thrasymachus is just". In the former case, false belief would occur because one wrongly believes that the beautiful is ugly rather than beautiful, in the latter because one wrongly believes that Theaetetus is beautiful rather than ugly.

T. endorses the first reading on the ground that in the allodoxia passage the soul is meant to decide on the basis of reasoning, and not on the basis of the evidence at hand. His argument runs as follows:

while it is true that the act of knowing Theaetetus, insofar as it is carried out by the soul, will always lead to a propositional expression (such as: «Yes, the man I now see is Theaetetus»), it is equally true that in this case [of the soul by itself in itself] the soul is not required to decide, based on reasoning, whether the person 
it sees is Theaetetus. For behind this cognisance there lies an act of direct apprehension. In this case, no à $\lambda \lambda$ o $\delta$ o $\xi$ ía can arise, since the doxai are ensured by the evidence at hand. The problem lies in ascertaining whether the same kind of evidence may also be found for general concepts such as beauty and justice. The answer can only be a negative one - for else it would be impossible to account for the fact that men constantly make mistakes with regard to things of this sort. If this is the case, we have found one way to explain the existence of $\dot{\alpha} \lambda \lambda_{0} \delta \delta_{o} \xi i$, namely by adducing the fact that no direct - and thus infallible - knowledge of the ideas is available to man. Indeed, it can hardly be a coincidence that all the examples Socrates presents in order to

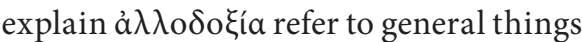
(such as the beautiful, the just, the odd, the ox, the horse, etc.), i.e. things the only possible knowledge of which is not «by acquaintance» - as in the case of individual objects such as Theaetetus - but «by description» (pp. 8-9).

He consequently argues that doxa $_{\mathrm{i}}$ is at issue in the second and third part of the dialogue, replacing the other type of doxa which was the object of the first part of the dialogue, namely doxa . However, one might have some reservations regarding the role of doxa $a_{\mathrm{i}}$ in the second and third part of the Theaetetus, also by taking into account the reading $T$. offers of the allodoxia passage.

For one thing, according to T., doxa $a_{\mathrm{i}}$ is firstly employed in the aviary passage (p. 57). ${ }^{12}$ There Socrates illustrates the occurrence of false beliefs by distinguishing actual and potential knowledge. Learning is remembering the things we once learned or, in the terms of this analogy, grasping the right item from our aviary (soul). Error, on the other hand, is grasping the wrong item of knowledge. In both cases the soul actualizes an item, i.e. what is potentially known, that is completely and fully possessed, but only latently. T. argues that in this passage Theaetetus and Socrates explain the formation of false beliefs turning to the doxa $_{\mathrm{i}}$ of the inner dialogue, and not to sense-perception.

Nevertheless, one might argue that while it is true that in the aviary passage the judgment is not the result of sense-perception, it is also true that Socrates and Theaetetus seem to understand knowledge in an empiricist manner: ${ }^{13}$ the objects are either grasped or not, and when grasped, they are completely known and at the soul's disposal. The underlying assumption is that these objects are monolithic: they can only be either completely known (possessed) or completely ignored (not possessed), and thus it is not possible to have an imprecise knowledge of them. Yet, this does not seem to be the case in the inner dialogue. ${ }^{14}$ The soul by itself in itself reflects upon complex objects - such as justice itself or the beautiful itself - that can be thought under different perspectives. Starting from a cognition characterized by a lack of clarity, the soul undergoes a dialogue with itself precisely because of this confusion. This seems also to emerge from the aforementioned quote of T.: allodoxia occurs in the cases in which the soul inquires about objects it cannot possess - i.e. of which it does not have the evidence at hand - since, if it could have contact with what is inquired about (general concepts) and possess them, the process of reflection would become obsolete.

T. also argues that $\operatorname{doxa}_{\mathrm{i}}$ is at issue in the third part of the dialogue insofar as the object of this final section is knowledge in general (p. 57). In so doing, he pays special attention 
to the third definition of logos, according to which knowledge is true judgment accompanied by the distinguishing mark. T.'s argument runs as follow: Socrates refutes this definition on the ground that the final assent of the reasoning of soul by itself in itself is doxa. Although the philosopher seeks to 'pursue a kind of knowledge based on logos (through discursive reasoning founded on the act of giving an account), [...] he remains bound to doxa' (p. 24) as 'doxa represents a non-trascendible epistemological level' (p. 22).

At this point some scholars might object that the inner dialogue is not at stake in this passage. What would make them hesitant to accept T.'s interpretation is the fact that that the passage alludes to the conceptual apparatus of the wax tablet rather than to that of the inner dialogue..$^{15}$ By insisting that the object of the third definition of logos is Theaetetus rather than man, ${ }^{16}$ and that it is based upon the imprint we have of him in our soul, one might argue that the belief arises from perception and memory, and not from reasoning. Since, in the wax tablet passage, the belief is ultimately an interaction between perception and thought which relies heavily on the content of sense-perception, ${ }^{17}$ the passage conveys the idea that the soul decides on the basis of the evidence at hand rather than on the basis of reasoning. ${ }^{18}$ So conceived, the belief would not be as much the result of reasoning as of sense-perception and memory. This, it could be maintained, seems also to arise from the aforementioned quote of T.: the act of knowing Theaetetus qua person is based on an act of direct apprehension, and not an act of reasoning. On the contrary, the soul undergoes the process of reflection, as envisioned in the soul by itself in itself, when it inquires about general concepts such as justice, beauty, or man.

Yet, it could be argued in turn that the distinguishing mark of the third definition of knowledge does not apply exclusively to perceptual features or individual things. ${ }^{19}$ Ronald Polansky 1992, p. 231 elucidates this point by arguing that:

Socrates makes clear that he is not merely concerned with individual things when he suggests we may have a true opinion and account «concerning whatever of the things that are» (208 e 3). Their present account of account surely allows them to pick out the peculiar features of a genus or a species at least as well as of individuals. Moreover, Socrates' objection to this account of account ignores that his example is of something individual; it works regardless of what the object might be.

This broadening of the range of things to which the distinguishing mark refers would imply that the object of the passage is all the things that are; i.e., particular and general things. Nonetheless, someone could still object that so interpreted the passage refers to a broader conception of belief than that of the allodoxia passage: in the latter case Socrates refers exclusively to the general concepts that are grasped through a process of reflection the dialogue of the soul by itself in itself. In the former case, however, Socrates remains vaguer and refers both to particular things and general concepts without assuming that the belief is the result of rational reflection. Consequently, the upshot would be that $\operatorname{doxa}_{\mathrm{i}}$, as interpreted by T., would be too narrow to explain the refusal of the last attempt to understand logos in the third part of the Theaetetus.

All things considered, T.'s book is a stimulating study that offers new perspectives on Plato's epistemology. By engaging in a fascinating and heated debate with contemporary scholars, it provides a lucid analysis of philosophical problems that are far from being irrelevant 
for any scholar working in this field. One may agree or disagree with T.'s views; yet, there can be hardly doubt that this is a fruitful intellectual journey that is worth taking.

\section{BIBLIOGRAPHY}

Bostock 1988: D. Bostock, Plato's Theaetetus, Oxford University Press, New York, 1988.

Burnyeat 1990: M. F. Burnyeat, The Theaetetus of Plato, translated by M. J. Levett, Hackett Publishing Company, Indianopolis, 1990.

Casertano 1996: G. Casertano, Il nome della cosa: linguaggio e realtà negli ultimi dialoghi di Platone, Loffredo, Napoli, 1996.

Chappell 2004: T. Chappell, Reading Plato's Theaetetus, Academia Verlag, Sankt Augustin.

Cherniss 1936: H. Cherniss, 'The Philosophical Economy of the Theory of Ideas', "The American Journal of Philology» 4 (1936), 445-456.

Cornford 1935: F. M. Cornford, Plato's Theory of Knowledge, Routledge, London, 1935.

Ferrari 2011: F. Ferrari, Platone:Teeteto, BUR, Milano, 2011.

Giannopoulou 2013: Z. Giannopoulou, Plato's Theaetetus as a Second Apology, Oxford University Press, Oxford, 2013.

Gonzalez 2007: F. Gonzalez (2007), 'Wax Tablets, Aviaries, or Imaginary Pregnancies? On the Powers in Theaetetus' Soul', «Etudes Platoniciennes» 4 (2007), 273-293.

Leslz (2001): W. Leslz, 'Pourquoi des formes? Sur quelques-unes des raisons pour lesquelles Platon a conçu l’hypothèse des formes intelligibles', in J.Pradeau (ed.), Platon: les formes intelligibles. Sur la forme intelligible et la participation dans les dialogues platoniciens, PUF, Paris 2001, 87-127.

Polansky 1992: R. M. Polansky, Philosophy and Knowledge: A Commentary on Plato's Theaetetus, Bucknell University Press, London, 1992.

Sedley 2004: D. Sedley, The Midwife of Platonism: Text and Subtext in Plato's Theaetetus, Oxford University Press, Oxford, 2004.

Trabattoni 2011: F. Trabattoni, Platone:Fedone, Einaudi, Turin, 2011.

Trabattoni 2016: F. Trabattoni, Essays on Plato's Epistemology, Leuven University Press, Leuven, 2016.
Vogt 2012: K. M. Vogt, Belief and Truth: A Skeptic Reading of Plato, Oxford University Press, Oxford, 2012.

Werner, Daniel S., 'Rhetoric and Philosophy in Plato's Phaedrus', «Greece \& Rome» 57 (2010), 21-46.

White 1992: N. P. White, 'Plato's Metaphysical Epistemology', in R. Kraut (ed.), The Cambridge Companion to Plato, Cambridge University Press, Cambridge 1992, 227-310.

\section{NOTES}

1 The first six essays discuss the problem of knowledge in the Theaetetus, while the final eight essays discuss the problem of knowledge in other dialogues, such as the Cratylus, the Republic, the Protagoras, the Parmenides, and the reception of the so called 'theory of ideas' in Aristotle.

2 T. analyses Franco Ferrari's and David Sedley's interpretations in chapters 5 and 6 respectively. See Sedley 2004 and Ferrari 2011. T. argues that both of them follow, to some extent, Cornford's interpretation of the Theaetetus.

3 Cfr. Trabattoni 2011, LXVIII-LXXII.

4 See especially pp. 38-43 and 210-212.

5 See also Vogt 2012. She argues that belief and knowledge are two different cognitive powers related to two different objects. Nevertheless, this does not exclude the possibility of deficiently directing the power of belief towards intelligible objects, producing what Vogt calls "beliefs with knowledge". She describes these states as follows: "they provide belief, but they do not seem to be bare of understanding (aneu nou), and they are not ugly and blind [...] such belief with knowledge is belief about the Good (rather than belief about the good), but it self- consciously is not knowledge of the Good' (pp. $22 ; 24)$. Because of this, although she agrees that we can have belief about objects of knowledge, she nonetheless holds that there is an ontological distinction between the objects of belief and the objects of knowledge.

6 Cfr. Cherniss 1936, 445-456 and White 1992, 227-310.

7 Cfr. Leslz 2001, 123-127.

8 Symp. 211 a 2-5.

9 See Soph. 234 c 6.

10 See Werner 2010, 35.

11 Another piece of evidence for the transcendence of the being that really is (őv $\tau \omega \varsigma$ ৎ ôv) comes from Plato's Sophist. In line with the second navigation of the Phaedo,

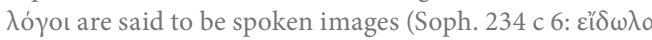
$\lambda \varepsilon \gamma \dot{o} \mu \varepsilon v a)$. Our reference to the being that really is is not direct but is rather mediated through images. An image (Soph. 240 a 7: $\varepsilon^{\prime \prime} \delta \omega \lambda \mathrm{ov}$ ) is not (a) the being that really is

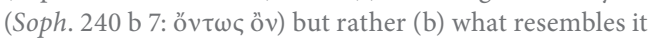
(Soph. 240 b 2: ả $\lambda \chi$ Ėoเkòs); it is that in which that which is not is woven together with that which is. This is the 


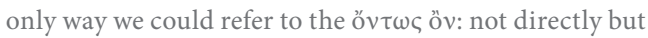
through the imperfect representations of images. That is to say, there is an ontological difference between real beings and images that cannot be overcome no matter how much we revise our images. In this regard, see the analogous remarks of T. in Plato's Cratylus (chapter 7): 'But even in the case in which an image were fashioned as it ought to, so as to contain all the elements necessary for it to be a good imitation of the thing in question, it would still be something other than the thing itself. If a god were to fashion a Cratylus not by coping him as a painter would do but by perfectly reproducing all his characteristics, the outcome would not be an image of Cratylus, but a second Cratylus (432 b 4-c5). Indeed, the correctness of an image is not to be found in the reproduction of an identical copy, for else the image would lose its nature qua image (432 d 1-3),' p.125. See also Casertano, 1996. 12 Theait. $196 \mathrm{~d} 1-200 \mathrm{~d} 4$.

13 Cfr. Chappell 2004, 184-192.

14 According to Francisco Gonzalez 'with the definition of knowledge as true judgment and the models of the wax tablet and the aviary that accompany it, this more fundamental power the soul has of examining and striving for being and truth by means of engaging in dialogue with itself is lost from view.' Cfr. Gonzalez 2007, 288.

15 Cfr. Burnyeat 1990, 220-221; 227-9 and Bostock 1988, 225-236

16 The distinguishing mark of Theaetetus is having "a snub nose and prominent eyes” (Theait. 209 c). Cfr. Sedley 2004, 174-175.

17 See Sedley 2004, 136-137.

18 As David Bostock put it: 'if I can refer to something without describing it when I am perceiving it, it is plausible to suppose that this is because my perception of it gives me some kind of « casual contact» with the thing. This is the main idea behind the so called « casual theory of perception», according to which to perceive a thing is -very roughly - to have experiences that are caused by that thing [...] the example that he uses (my remembering Theaetetus) is much more plausibly regarded as one in which it is my casual contact with the thing, and not my ability to describe it, that explains why it is that thing that I am thinking of.' Bostock 1988, 230; 233.

19 Cfr. Shields 1999, 116-118; Giannopoulou 2013, 176-

177. See also Chappell 2004, 221. 